Article

\title{
Protective Effects of Olive Leaf Extract on Acrolein-Exacerbated Myocardial Infarction via an Endoplasmic Reticulum Stress Pathway
}

\author{
Yuyu Xu ${ }^{1}$, Lixing $\mathrm{Wu}^{1,2}$, Aochang Chen ${ }^{1}$, Chaoqi $\mathrm{Xu}^{1}$ and Qing Feng ${ }^{1, *}$ \\ 1 Department of Nutrition and Food Hygiene, Nanjing Medical University, Nanjing 211166, China; \\ yuyuxuup@njmu.edu.cn (Y.X.); foxwlx@126.com (L.W.); xiaocc1992@njmu.edu.cn (A.C.); \\ chaoqixu2015@163.com (C.X.) \\ 2 Department of Cardiology, Jiangsu Province Hospital, The First Affiliated Hospital with Nanjing Medical \\ University, Nanjing 210000, China \\ * Correspondence: qingfeng@njmu.edu.cn; Tel.: +86-25-8686-8455; Fax: +86-25-8686-8499
}

Received: 2 January 2018; Accepted: 1 February 2018; Published: 7 February 2018

\begin{abstract}
Many studies reported that air pollution particulate matter (PM) exposure was associated with myocardial infarction (MI). Acrolein representing the unsaturated aldehydes, the main component of PM, derives from the incomplete combustion of wood, plastic, fossil fuels and the main constitute of cigarette smoking. However, the effect of acrolein on MI remains not that clear. In the current study, the effect of acrolein-exacerbated MI was investigated. In vivo, male Sprague-Dawley rats received olive leaf extract (OLE) followed by acrolein, then isoprenaline (ISO) was received by subcutaneous injection to induce MI. Results showed that the expression levels of GRP78 and CHOP, two major components of endoplasmic reticulum (ER) stress were higher in the combination of acrolein and ISO than those in ISO treatment. The apoptosis marker, Bax, was also higher while the anti-apoptosis indicator, $\mathrm{Bcl} 2$ expression was lower both at protein and mRNA levels in the combination group. Also, the acrolein-protein adducts and myocardial pathological damage increased in the combination of acrolein and ISO relative to the ISO treatment. Besides, cardiac parameters, ejection fraction (EF) and fractional shortening (FS) were reduced more significantly when acrolein was added than in ISO treatment. Interestingly, all the changes were able to be ameliorated by OLE. Since hydroxytyrosol (HT) and oleuropein (OP) were the main components in OLE, we next investigated the effect of HT and OP on cardiomyocyte H9c2 cell apoptosis induced by acrolein through ER stress and Bax pathway. Results showed that GRP78, CHOP and Bax expression were upregulated, while Bcl2 expression was downregulated both at the protein and mRNA levels, when the $\mathrm{H} 9 \mathrm{c} 2$ cells were treated with acrolein. In addition, pretreatment with HT can reverse the expression of GRP78, CHOP, Bax and Bcl2 on the protein and mRNA levels, while there was no effect of OP on the expression of GRP78 and CHOP on the mRNA levels. Overall, all these results demonstrated that OLE and the main components (HT and OP) could prevent the negative effects of acrolein on myocardium and cardiomyocytes.
\end{abstract}

Keywords: acrolein; apoptosis; olive leaf extract; hydroxytyrosol; oleuropein

\section{Introduction}

Cardiovascular diseases still remain the main cause of increased mortality worldwide, among which Ischemic heart disease and stroke are the most prevalent [1,2]. As to ischemic heart disease, myocardial infarction (MI) is an acute status of unbalance between decreased coronary flow and the demand of the myocardium. A growing number of studies demonstrate the significant association between myocardial infarction and air pollution exposure [3-6]. For instance, epidemiological studies 
showed that short-term exposure of particulate matter (PM) exacerbated myocardial infarction. In other words, the patients suffering from ischemic heart diseases were more susceptible to particulate matter exposure [3,7]. Furthermore, carbonyl compounds (aldehydes and ketones) proved to be the key molecular components of the water soluble part of PM [8]. Particularly, acrolein, an ubiquitously unsaturated aldehyde was generated during the incomplete combustion of wood, plastic, fossil fuels and the main constitute of cigarette smoking [9]. In addition, it can be discovered in carbohydrate-rich food that is cooked at high temperature as a result of the Maillard reaction [10]. The average concentration of acrolein was $2.3 \pm 1.0 \mu \mathrm{g} / \mathrm{m}^{3}$ at a heartland of Beijing site from June to October in 2008 [11]. Also, acrolein emitted per cigarette is 10-500 $\mu \mathrm{g}[12,13]$. Acrolein readily forms covalent adducts with proteins and DNA due to being a strong electrophile, which result in cytotoxicity that induces various diseases including cardiovascular diseases [14]. Recent studies show that exposure to acrolein increased cardiovascular disease risk [15-17]. However, the association between acrolein and myocardial infarction has not yet been elaborated clearly.

OLEs from olive leaves and branches are rich in polyphenols, of which oleuropein (OP) and hydroxytyrosol (HT) are the major phytochemical components that play important roles in anti-atherosclerotic, cardioprotective and hypoglycemic aspects [18]. Likewise, OP and HT are indispensable ingredients in the well-known Mediterranean diet that is associated with a low incidence rate of cardiovascular diseases [19-21]. Recent studies show that the protective effects of olive leaf extract (OP and HT) on cardiovascular diseases, but the explanation of mechanisms are severely insufficient [22-24].

In the current study, in vivo, we investigated acrolein exacerbated myocardial infarction that was induced by ISO in rats. Besides, the oral administration of OLE can reverse heart damage to some extent. In vitro, we explored the protective effects of HT and OP against the acrolein-inducing cardiomyocyte $\mathrm{H} 9 \mathrm{c} 2$ cell apoptosis through ER stress and $\mathrm{Bcl} 2$ / Bax pathways.

\section{Results}

\subsection{Effect of OLE on Aggravated Myocardial Injury Induced by Acrolein}

Following the HE staining, there were no apparent changes in the control group; the structure of the myocardium was normal and cells were well-arranged. In the ISO treatment group, the structure of myocardium was disorderly and myocardial cells presented widespread edema. Besides, distinct infiltration of inflammatory cells were observed. In the combination of acrolein and ISO treatment group, the tissue was suffering more serious damage relative to the ISO group. Cell gaps grew bigger, the cell nucleus was not clear and more severe infiltration of inflammatory cells was observed. In the pretreatment with OLE (200 mg/kg/day, $400 \mathrm{mg} / \mathrm{kg} /$ day) groups, the myocardial tissue damage was reduced, and infiltration of inflammatory cells was decreased (Figure 1A). As shown in Figure 1B, the heart weight over body weight ratio in the combination of ISO and arolein treatment group was higher than that in ISO treatment group. However, the accretion can be reversed by OLE to some extent. Results from echocardiography showed that the parameters of cardiac systolic function, ejection fraction (EF) and fractional shortening (FS), were lower in the combination of ISO and acrolein treatment group than in the ISO treatment group. Also, OLE pretreatment reversed the value of EF and FS (Figure 1C,D). Furthermore, the acrolein-protein adduct, myocardial enzyme CK-MB and LDH were detected from the collected serum. It is obvious that the concentrations of acrolein-protein adducts, CK-MB and LDH were highest in the combination of ISO and acrolein treatment group, and the increase was reversed by OLE pretreatment (Figure 1E). All the results demonstrated that acrolein worsened the myocardial injury induced by ISO, and that OLE can attenuate the damage significantly. 


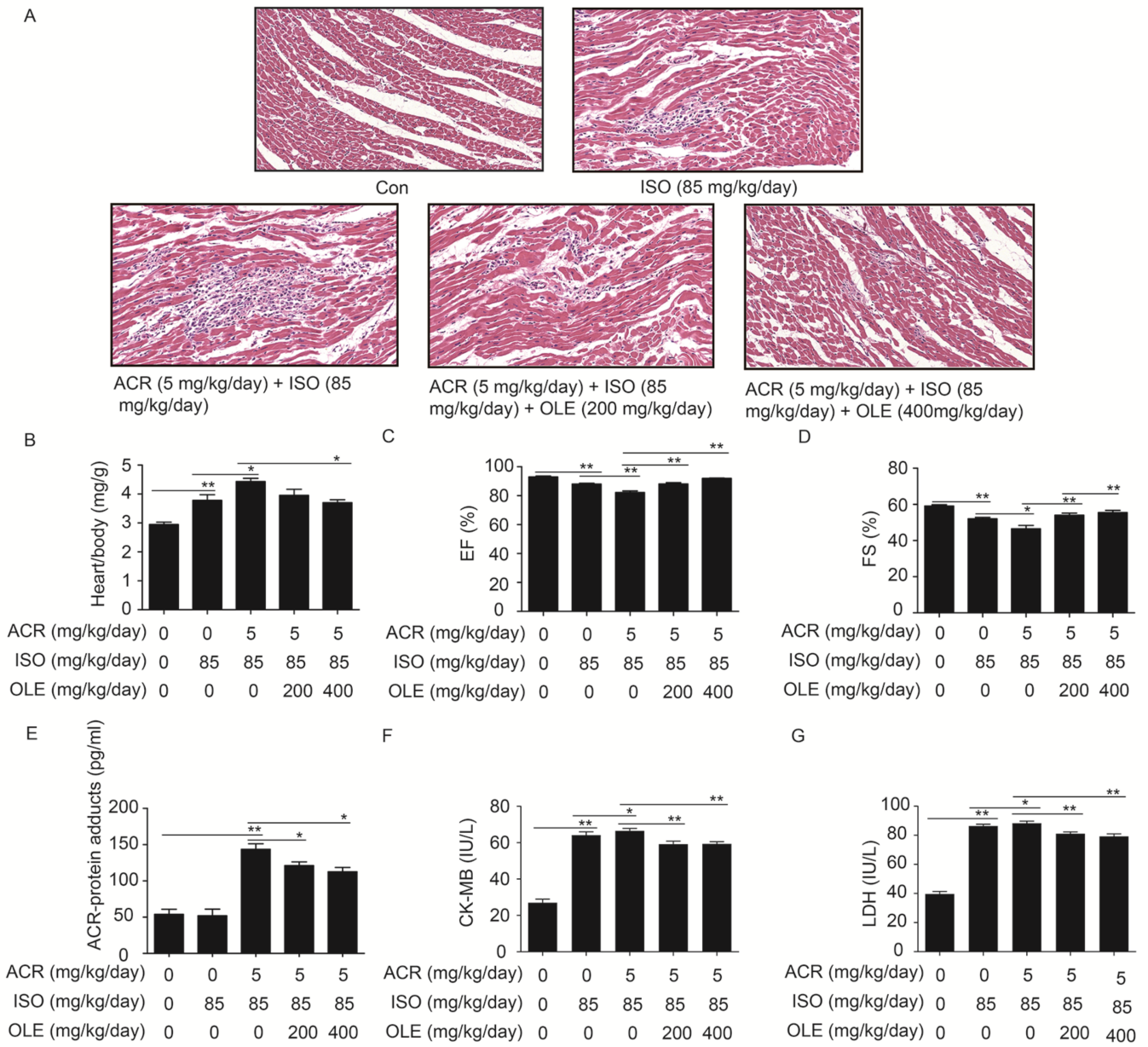

Figure 1. Effect of olive leaf extract (OLE) on aggravated myocardial injury induced by acrolein in rats. (A) Representative photographs of heart sections stained with haematoxylin and eosin $(200 \times)$ in different groups; (B) quantitative analysis of the heart weight over body weight ratio in different groups; (C,D) Quantitative analysis of left ventricular FS (\%) and EF (\%), as tested by echocardiography; (E) the levels of acrolein-protein adducts in different groups, as measured by ELISA; $(\mathbf{F}, \mathbf{G})$ the levels of myocardial enzyme CK-MB and LDH in different groups, as measured by ELISA. ${ }^{*} p<0.05,{ }^{* *} p<0.01$.

\subsection{Effect of OLE on Myocardial Apoptosisand Infiltration of Macrophagesinduced by Acrolein}

To explore the effect of OLE on myocardial apoptosis, we performed immunohistochemical staining of Bax. The expression of Bax in the combination of ISO and arolein treatment group was strongly positive, and the distribution of Bax was disordered. As expected, the increased expression of Bax was reversed by OLE ( $200 \mathrm{mg} / \mathrm{kg} /$ day, $400 \mathrm{mg} / \mathrm{kg} /$ day) in a dose-dependent manner (Figure 2A). To explore the infiltration of macrophages, immunohistochemical staining of $\mathrm{F} 4 / 80$ was conducted. We observed massive macrophage cell infiltration and overexpression of F4/80 in the combination of ISO and arolein treatment group. Also, OLE ( $200 \mathrm{mg} / \mathrm{kg} /$ day, $400 \mathrm{mg} / \mathrm{kg} /$ day) can attenuate the infiltration of macrophages in a dose dependent manner, which has been marked by arrows (Figure 2B). 
Bax
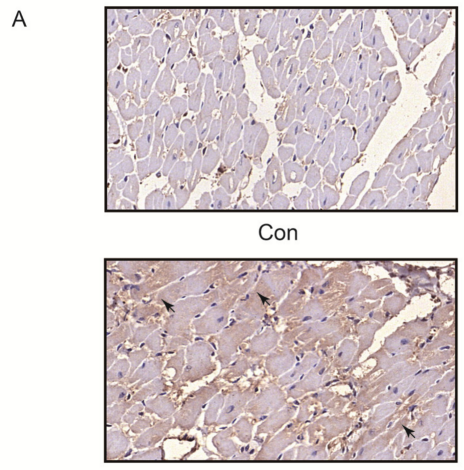

ISO (85 mg/kg/day)

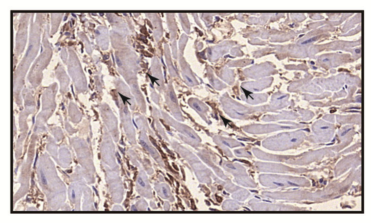

ACR ( $5 \mathrm{mg} / \mathrm{kg} /$ day $)+$ ISO (85 $\mathrm{mg} / \mathrm{kg} /$ day)

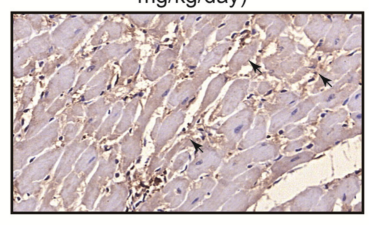

ACR $(5 \mathrm{mg} / \mathrm{kg} / \mathrm{day})+\mathrm{ISO}(85$ $\mathrm{mg} / \mathrm{kg} /$ day $)+$ OLE (200 mg/kg/day)

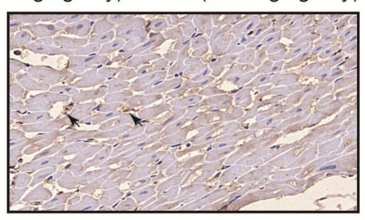

ACR $(5 \mathrm{mg} / \mathrm{kg} / \mathrm{day})+$ ISO (85 $\mathrm{mg} / \mathrm{kg} /$ day $)+$ OLE (400 mg/kg/day)
$\mathrm{F} 4 / 80$

B

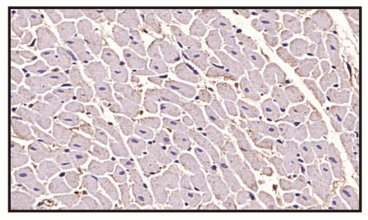

Con

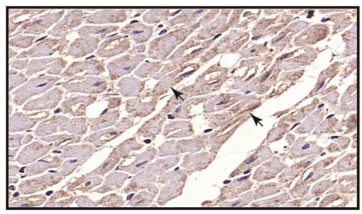

ISO (85 mg/kg/day)

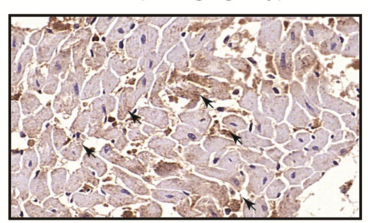

ACR (5 mg/kg/day) + ISO (85 $\mathrm{mg} / \mathrm{kg} / \mathrm{day}$ )

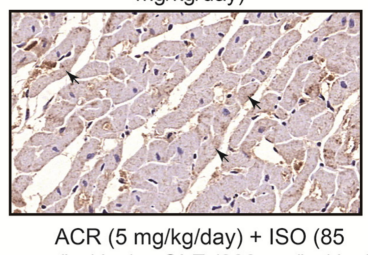

$\mathrm{mg} / \mathrm{kg} /$ day $)+$ OLE $(200 \mathrm{mg} / \mathrm{kg} /$ day $)$

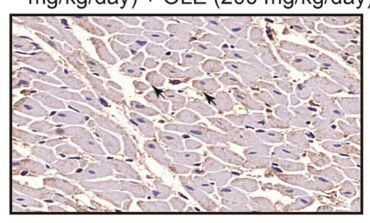

ACR $(5 \mathrm{mg} / \mathrm{kg} / \mathrm{day})+$ ISO $(85$ $\mathrm{mg} / \mathrm{kg} /$ day $)+$ OLE (400 mg/kg/day)

Figure 2. Effect of OLE on myocardial apoptosis and infiltration of macrophages induced by acrolein. (A,B) Representative photographs of heart sections with immunohistochemical staining of Bax and F4/80 $(400 \times)$ in different groups.

\subsection{Effect of OLE on Myocardium Protection through the Pathway of ERS and Bcl2/Bax}

To further confirm the mechanism on acrolein-inducing the increase in myocardial injury, the critical molecules GRP78 and CHOP in the ER stress pathway and apoptosis-related molecules $\mathrm{Bcl} 2 / \mathrm{Bax}$ were examined. The expression of GRP78, CHOP and Bax at the protein and mRNA levels were increased more obviously in the co-treatment of acrolein and ISO rats than that in ISO treatment rats in comparison with controls. Meanwhile, Bcl2 was downregulated much more remarkably in the co-treatment of acrolein and ISO group than in the ISO treatment group. All the altered expression of GRP78, chop, Bax and Bcl2 at the protein and mRNA levels were reversed dramatically by pretreatment with OLE ( $200 \mathrm{mg} / \mathrm{kg} /$ day, $400 \mathrm{~kg} / \mathrm{kg} /$ day) (Figure $3 \mathrm{~A}-\mathrm{F})$. These data showed that acrolein exacerbated myoardialinjury induced by ISO through upregulation of GRP78, chop, Bax while showing the downregulation of $\mathrm{Bcl} 2$, which resulted in myocardial cell apoptosis. However, all the changes were ameliorated by OLE apparently. 


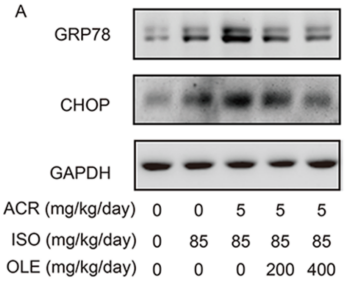

$\mathrm{c}$

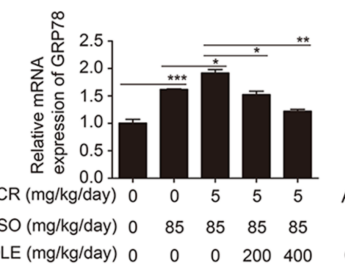

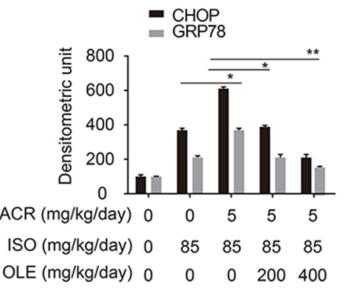

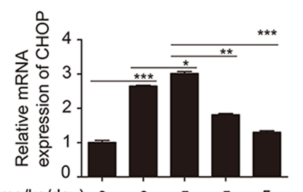

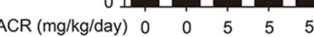
ISO (mg/kg/day) $0 \begin{array}{lllllllllllll}0 & 85 & 85 & 85 & 85 & \text { ISO (mg/kg/day) } & 0 & 85 & 85 & 85 & 85\end{array}$ OLE (mg/kg/day) $0 \begin{array}{llllllllllll} & 0 & 0 & 200 & 400 & \text { OLE }(\mathrm{mg} / \mathrm{kg} / \mathrm{day}) & 0 & 0 & 0 & 200 & 400\end{array}$

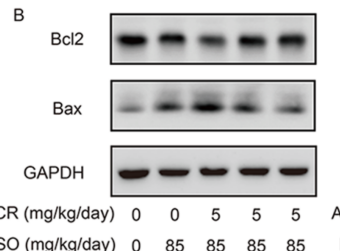

$\begin{array}{lccccc}\mathrm{SO} O(\mathrm{mg} / \mathrm{kg} / \mathrm{day}) & 0 & 85 & 85 & 85 & 85 \\ \mathrm{OLE}(\mathrm{mg} / \mathrm{kg} / \mathrm{day}) & 0 & 0 & 0 & 200 & 400\end{array}$

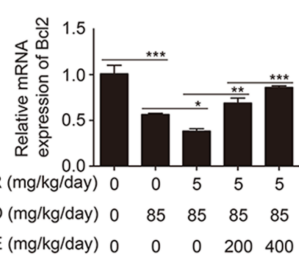

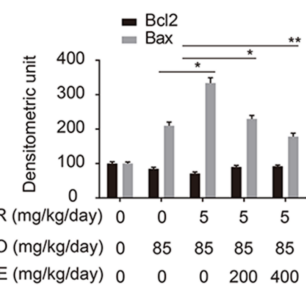

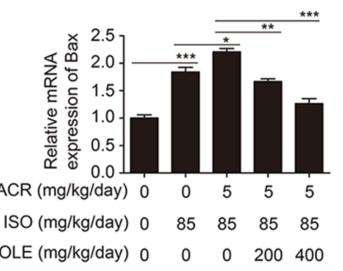

Figure 3. Effect of OLE on myocardium protection through the pathway of ERS, Bcl2/Bax in rats. $(\mathbf{A}, \mathbf{B})$ The protein expression of GRP78, CHOP, Bcl2 and Bax in different groups, as detected by Western blotting; (C-F) The mRNA expression of GRP78, CHOP, Bcl2 and Bax in different groups, as detected by qRT-PCR. ${ }^{*} p<0.05,{ }^{* *} p<0.01$ and ${ }^{* * *} p<0.001$.

\subsection{HT and OP Reversed the H9c2 Cells Apoptosis Induced by Acrolein}

To explore which component of OLE plays an important role in protection against acrolein-induced myocardial injury, the main components of OLE, HT and OP were applied to cardiomyocyte $\mathrm{H} 9 \mathrm{c} 2$ cells. MTT assays, Hoechst 33258 staining and flow cytometry were performed in vitro to detect the cytotoxicity of acrolein and whether HT and OP could prevent cytotoxicity in H9c2 cells exposed to acrolein. As shown in Figure 4A, the reduction in cell viability was remarkable in a dose-dependent manner, when the $\mathrm{H} 9 \mathrm{c} 2$ cells were treated with acrolein at the indicated concentrations for $12 \mathrm{~h}$. The $\mathrm{IC}_{50}$ was $39.60 \mu \mathrm{M}$ ( $95 \% \mathrm{CI}$ (33.88 to 46.29$)$ ). There was no change observed in cell viability, when the H9c2 cells were exposed to HT and OP at the indicated concentrations for $24 \mathrm{~h}$ (Figure 4B). In addition, $\mathrm{H} 9 \mathrm{c} 2$ cells were pretreated with $\mathrm{HT}$ and OP at the indicated concentrations for $24 \mathrm{~h}$ followed by incubation with acrolein $(40 \mu \mathrm{M})$ for another $12 \mathrm{~h}$. The result from Figure $4 \mathrm{C}$ showed that HT and OP increased cell viability which was decreased by acrolein in a dose-dependent manner. When H9c2 cells were pretreated with OP $(20 \mu \mathrm{M})$ and HT $(5 \mu \mathrm{M})$ for $24 \mathrm{~h}$, followed by incubation with acrolein $(40 \mu \mathrm{M})$ for another $12 \mathrm{~h}$, Hoechst 33258 staining showed that OP and HT was able to protect $\mathrm{H} 9 \mathrm{c} 2$ cells from acrolein-induced apoptosis, as shown in Figure 4D,E. Besides, Annexin-V FITC/PI staining also showed that OP and HT could ameliorate acrolein-induced H9c2 cell apoptosis, which was analyzed by flow cytometry (Figure $4 \mathrm{~F}, \mathrm{G}$ ). The presented data indicated that HT reversed the $\mathrm{H} 9 \mathrm{c} 2$ cell apoptosis induced by acrolein. 


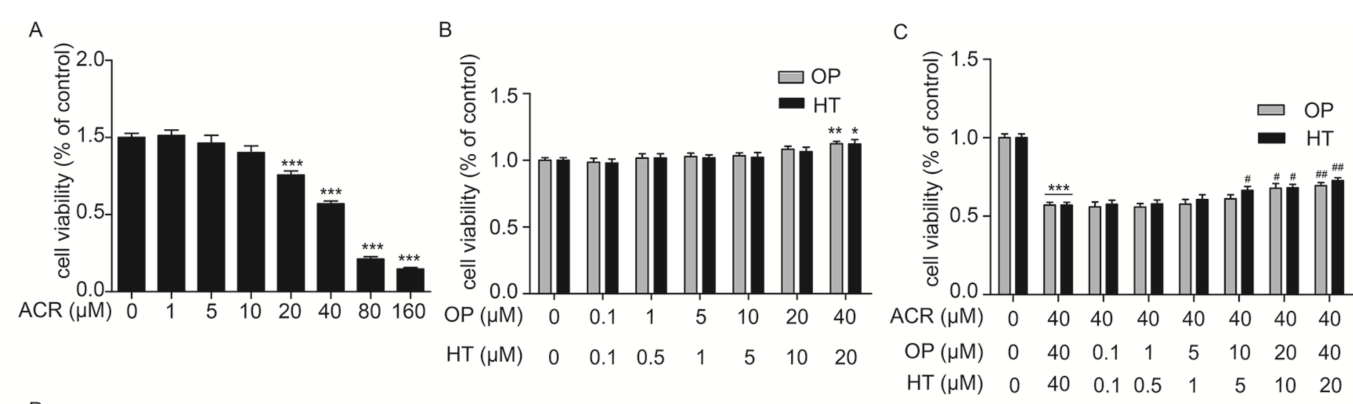

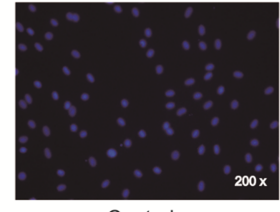

Control

E

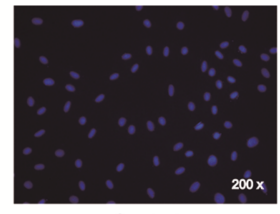

Control

F

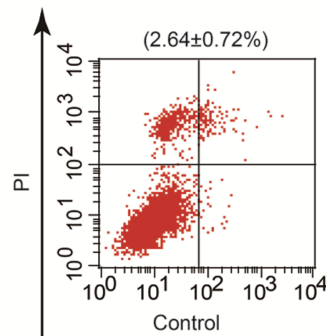

G

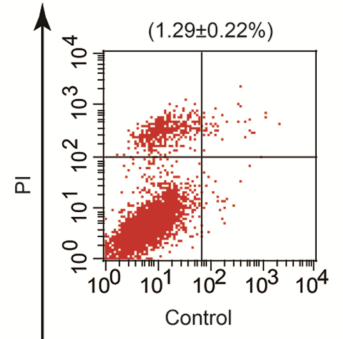

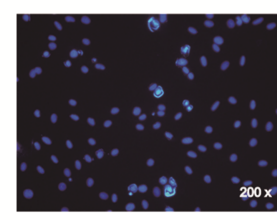

$\operatorname{ACR}(40 \mu \mathrm{M})$

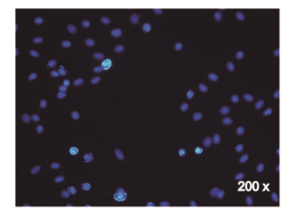

ACR $(40 \mu \mathrm{M})$

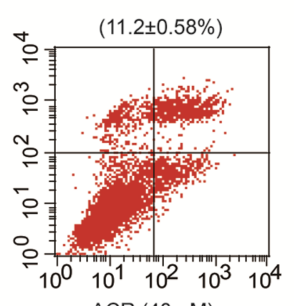

$\operatorname{ACR}(40 \mu \mathrm{M})$

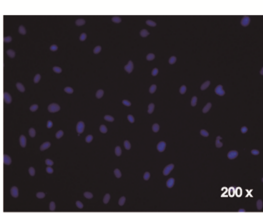

OP $(20 \mu \mathrm{M})$

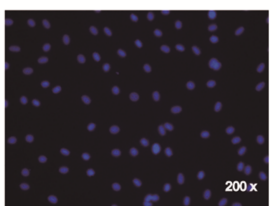

$\mathrm{HT}(5 \mu \mathrm{M})$

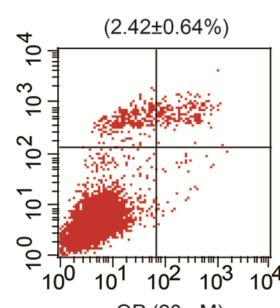

$\mathrm{OP}(20 \mu \mathrm{M})$

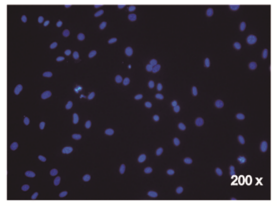

$\operatorname{ACR}(40 \mu \mathrm{M})+\mathrm{OP}(20 \mu \mathrm{M})$

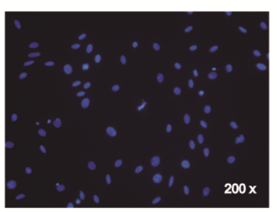

$\operatorname{ACR}(40 \mu M)+H T(5 \mu M)$

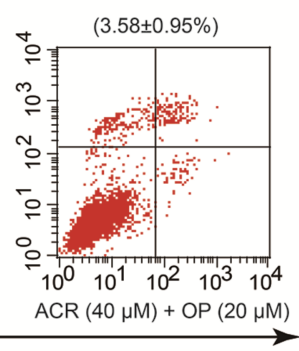

Annexin V FITC
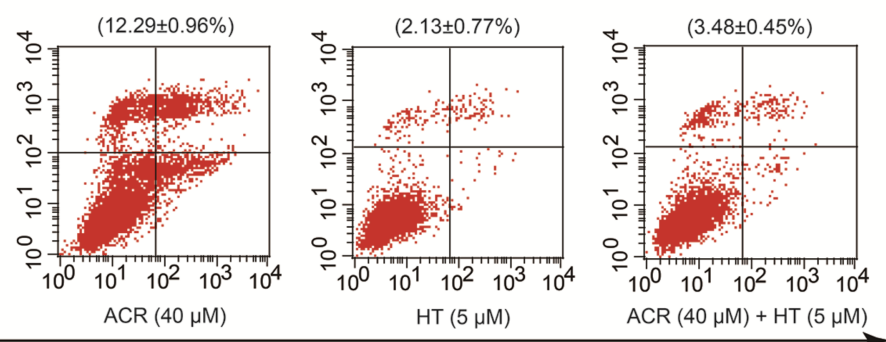

Annexin V FITC

Figure 4. Hydroxytyrosol (HT) and OP reversed the H9c2 cells apoptosis induced by acrolein. (A) The cell viability of $\mathrm{H} 9 \mathrm{c} 2$ after being treated with acrolein $(0,1,5,10,20,40,80,160 \mu \mathrm{M})$ for $12 \mathrm{~h}$, as measured by MTT assay; (B) The cell viability of H9c2 after treatment with HT $(0,0.1,0.5,1,5,10,20 \mu \mathrm{M})$ or OP $(0,0.1,1,5,10,20,40 \mu \mathrm{M})$ for $24 \mathrm{~h}$, as measured by MTT assay; (C) The cell viability of H9c2 after pretreatment with $\mathrm{HT}(0,0.1,0.5,1,5,10,20 \mu \mathrm{M})$ or OP $(0,0.1,1,5,10,20,40 \mu \mathrm{M})$ for $24 \mathrm{~h}$, and combination with acrolein $(40 \mu \mathrm{M})$ for another $12 \mathrm{~h}$, as measured by MTT assay; (D-G) the apoptosis rate of $\mathrm{H} 9 \mathrm{c} 2$ after pretreatment with $\mathrm{HT}(5 \mu \mathrm{M})$ and OP $(20 \mu \mathrm{M})$ for $24 \mathrm{~h}$, and the combination with acrolein $(40 \mu \mathrm{M})$ for another $12 \mathrm{~h}$, as detected by Hochest 33258 staining (original magnification is $200 \times$ ) and Annexin-V FITC/PI staining flow cytometry. Statistical differences to the controls were shown as ${ }^{*} p<0.05,{ }^{* *} p<0.01$ and ${ }^{* * *} p<0.001$. Statistical differences to the grouptreated with acrolein $(40 \mu \mathrm{M})$ solely were shown as ${ }^{\#} p<0.05$ and ${ }^{\# \#} p<0.01$. 


\subsection{Acrolein Altered the Expression of GRP78, CHOP, Bcl2 and Bax in H9c2 Cells}

To determine whether acrolein induced H9c2 cell apoptosis through the ER stress pathway and the mitochondrial pathway of apoptosis, key molecules, GRP78 and CHOP, of the ER stress pathway as well as $\mathrm{Bcl} 2$ and $\mathrm{Bax}$ from the Bcl-2 family of proteins were explored. The result showed that the expression of GRP78 and CHOP were increased after H9c2 cells were treated with acrolein $(20 \mu \mathrm{M})$ for the indicated time points. Moreover, the level of GRP78 reached the peak at $6 \mathrm{~h}$, then gradually returned to relatively lower levels. In addition, the level of $\mathrm{CHOP}$ reached the highest at $12 \mathrm{~h}$, and was then reduced at $24 \mathrm{~h}$ (Figure 5A). As shown in Figure 5B, the expression of GRP78 and CHOP was increased after H9c2 cells were treated with acrolein at indicated concentrations for $12 \mathrm{~h}$. In addition, it is obvious that the level of CHOP increased in a dose-dependent manner from 0 to $20 \mu \mathrm{M}$ and decreased at $40 \mu \mathrm{M}$ of acrolein. Furthermore, the expression of Bcl 2 or Bax was decreased or increased in a time-dependent manner, when $\mathrm{H} 9 \mathrm{c} 2$ cells were treated with acrolein $(20 \mu \mathrm{M})$ for the indicated time points (Figure 5C). As shown in Figure 5D, the expression of Bcl2 or Bax was decreased or increased in a dose-dependent manner, when $\mathrm{H} 9 \mathrm{c} 2$ cells were treated with acrolein at the indicated concentrations for $12 \mathrm{~h}$. As expected, the mRNA expression of GRP78, CHOP, Bcl2 and Bax was consistent with the protein level, respectively, in the two kinds of treatments (Figure 5E-K). Therefore, the pathway of ER stress and mitochondrial pathway of apoptosis were involved in the process of acrolein-induced $\mathrm{H} 9 \mathrm{c} 2$ cell apoptosis.
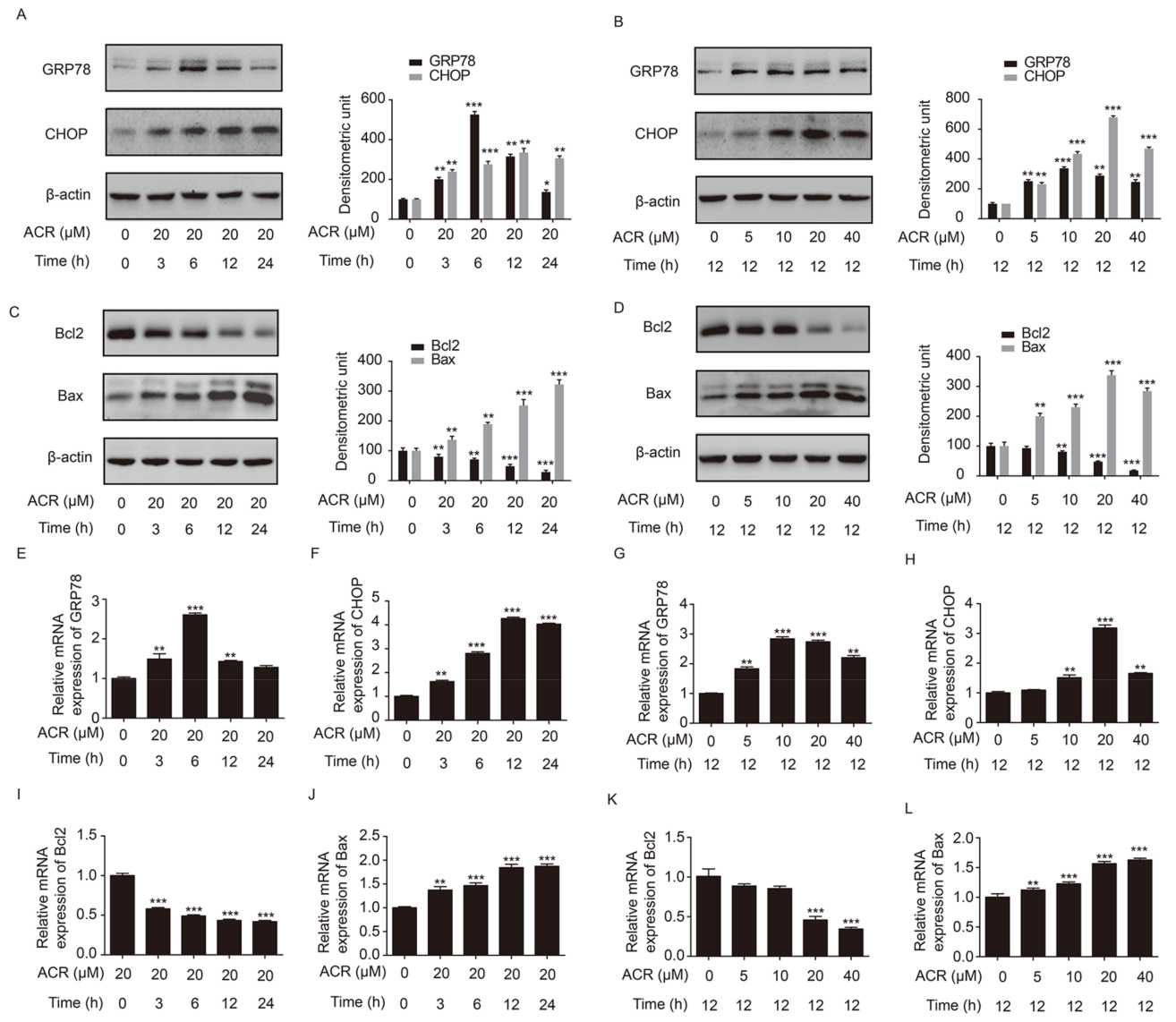

Figure 5. Acrolein altered the expression of GRP78, CHOP, Bcl2 and Bax in $\mathrm{H} 9 \mathrm{c} 2$ cells. $(\mathbf{A}, \mathrm{C}, \mathrm{E}, \mathrm{F}, \mathrm{H}, \mathbf{I})$ The expression of GRP78, CHOP, Bcl2 and Bax at the protein and mRNA levels after H9c2 cells were treated with acrolein $(20 \mu \mathrm{M})$ for the indicated time points $(0,3,6,12,24 \mathrm{~h})$, as measured by Western blotting and qRT-PCR; (B,D,G,H,J,K) The expression of GRP78, CHOP, Bcl2 and Bax at the protein and mRNA levels after the H9c2 cells were treated with acrolein $(0,5,10,20,40 \mu \mathrm{M})$ for $12 \mathrm{~h}$, as measured by Western blotting and qRT-PCR. ${ }^{*} p<0.05,{ }^{* *} p<0.01$ and ${ }^{* * *} p<0.001$. 
2.6. HT and OP Attenuated the Altered Expression of GRP78, CHOP, Bcl2 and Bax Induced by Acrolein in H9c2 Cells

To investigate whether HT and OP prevented H9c2 cell apoptosis through the ER stress pathway, the expression levels of GRP78, CHOP, and the the apoptosis makers $\mathrm{Bcl} 2$ and Bax were detected. As shown in Figure 6A,B, the levels of GRP78, CHOP and Bax were upregulated significantly when $\mathrm{H} 9 \mathrm{c} 2$ cells were treated with acrolein $(20 \mu \mathrm{M})$ for $12 \mathrm{~h}$. At the same time, $\mathrm{Bcl} 2$ expression was obviously reduced. However, the change of GRP78, CHOP, Bcl2 and Bax was reversed when H9c2 cells were pretreated with HT ( $5 \mu \mathrm{M})$ for $24 \mathrm{~h}$, followed by acrolein $(20 \mu \mathrm{M})$ treatment for $12 \mathrm{~h}$. Consistent with the protein expression, the altered expression of GRP78, CHOP, Bcl2 and Bax at the mRNA level due to acrolein was reversed by HT (Figure 6E-H). Besides, HT was replaced by OP $(20 \mu \mathrm{M})$ to treat the cells, and other treatments were the same as the HT treatment group. As shown in Figure 6C,D, the altered expression of GRP78, CHOP, Bcl2 and Bax was alleviated by OP. In addition, the mRNA expression of $\mathrm{Bcl} 2$ and Bax is consistent with the protein expression (Figure 6K,L). However, the mRNA expression of GRP78 and CHOP was not reversed by OP (Figure 6I,J), which is necessary to explore further.
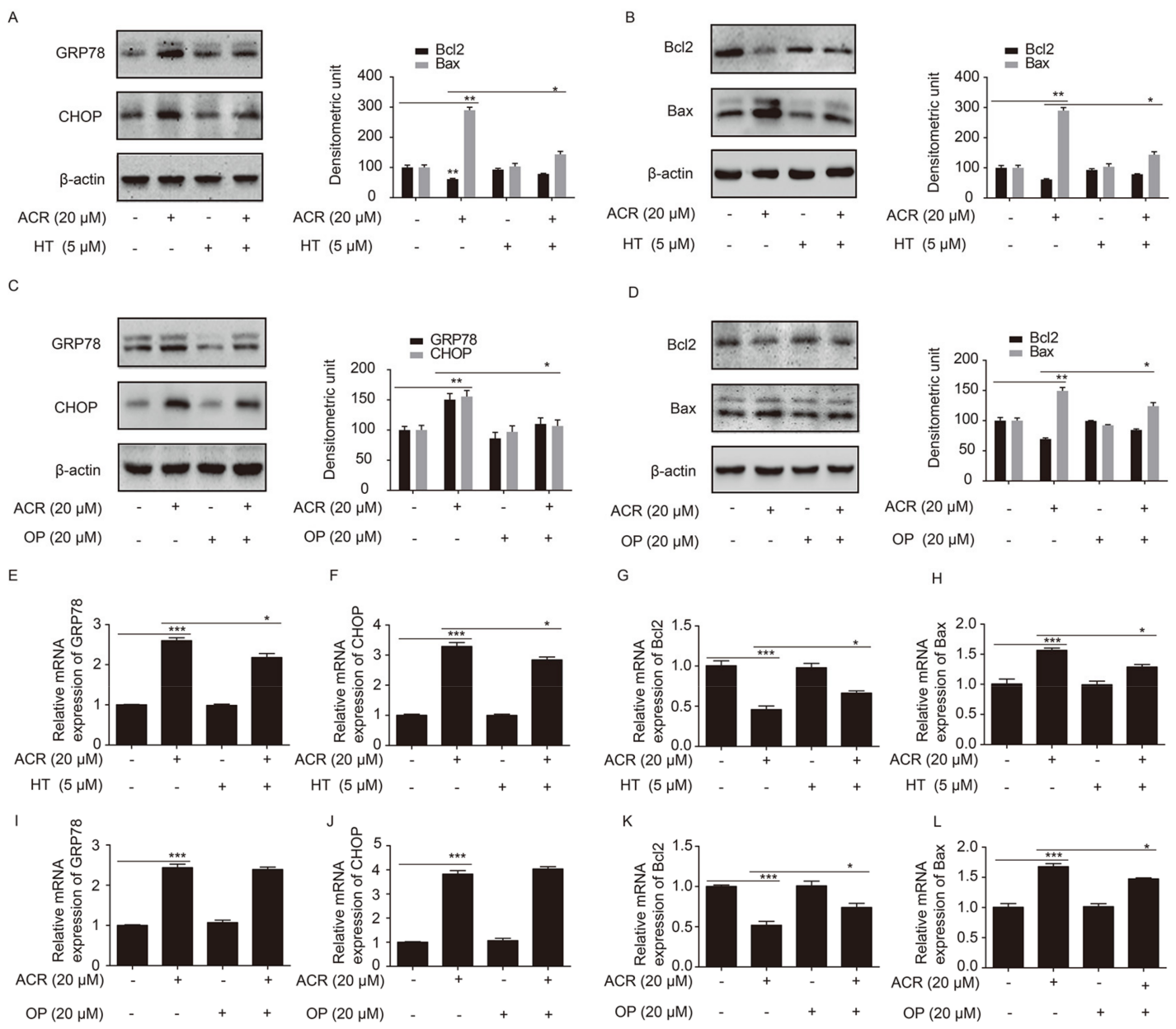

Figure 6. HT and OP attenuated the altered expression of GRP78, CHOP, Bcl2 and Bax induced by acrolein in H9c2 cells. (A,B,E-H) The expression of GRP78, CHOP, Bcl2 and Bax at the protein and mRNA levels after H9c2 cells were pretreated with HT $(5 \mu \mathrm{M})$ for $24 \mathrm{~h}$, and the combination with acrolein $(20 \mu \mathrm{M})$ for $12 \mathrm{~h}$, as measured by Western blotting and qRT-PCR. (C,D,I-L) The expression of GRP78, CHOP, Bcl2 and Bax at the protein and mRNA levels after H9c2 cells were pretreated with OP $(20 \mu \mathrm{M})$ for $24 \mathrm{~h}$, and the combination with acrolein $(20 \mu \mathrm{M})$ for $12 \mathrm{~h}$, as measured by Western blotting and qRT-PCR. ${ }^{*} p<0.05,{ }^{* *} p<0.01$ and ${ }^{* * *} p<0.001$. 


\section{Discussion}

In the current study, we evaluated the effect of acrolein on exacerbating MI induced by ISO and the protective effect of OLE on myocardium from myocardialinjury in vivo. Also, we found that the preventive effect of HT and OP on cardiomyocyte H9c2 cytotoxicity generated by acrolein in vitro through ER stress and Bcl2/Bax apoptosis pathways. To our knowledge, this is first report that shows that OLE and the main components (HT and OP) regulated the ER stress pathway in H9c2 cells and myoardial injury rats against acrolein. In addition, our results supported the notion that acrolein and related aldehyde consumption increased the myocardial sensitivity to ischemia [17]. Therefore, our data demonstrated that OLE with abundant polyphenols and the main components (HT and OP) were helpful in the prevention and treatment of myoardial injury from air pollution exposure, such as the unsaturated aldehyde acrolein. ER is a significantly specialized organelle that consists of a huge membranous network, which exerts a vital role in directing synthesis and folding of proteins, as well as calcium homeostasis and phospholipid synthesis in eukaryotic cells [25-27]. However, once stimuli from internal and external environments disrupt the balance of protein synthesis and folding, misfolded and unfolded proteins are accumulated in the ER lumen, named as ER stress, which activates the unfolded protein response (UPR) to remedy the unbalance of the ER function. Three branches of ER stress transducers are involved including inositol-requiring protein 1 (IRE1), protein kinase ER-like kinase (PERK) and activating transcription factor 6 (ATF6) [28]. Under normal conditions, the ER chaperone 78-KD glucose-regulated protein (GRP78) was bound to the three ER stress transducers (IRE1, PERK and ATF6). When the accumulation of misfolded and unfolded protein triggers ER stress, GRP78 will be dissociated from the three ER stress sensors, resulting in activation of these molecules, which can ameliorate cell damage from dysfunction and promote cell survival $[25,29]$. However, prolonged UPR is able to elicit cell apoptosis that is regulated by C/EBP-homologous protein (CHOP, also named as GADD153), the specific transcription factor of ERS, which mediates cell apoptosis through many molecular pathways, such as the suppression of anti-apoptotic protein Bcl2, activation of caspase-12 and c-JUN NH2-terminal kinase [30-32]. It is reported that ER stress is associated with the pathogenesis of cardiovascular diseases including myocardial infarction, hypertrophy and heart failure [33]. There is continuous hypoxia and ischemia in myocardial infarct area, which gives rise to multiple folding enzymes located in ER lumen inactivation that induces misfolded and unfolded protein accumulation and ERS, also, excessive ERS initiates cell apoptosis [34,35]. Moreover, Thuerauf et al. demonstrated that UPR was activated in cardiomyocytes under hypoxia and the mouse model of myocardial infarction [36]. Besides, a previous study has showed that the expression of CHOP was significantly increased in the samples from heart failure patients and $\mathrm{CHOP}$-deficient mice presented cardiac protective effects relative to wild-type mice, which verified that $\mathrm{CHOP}$ mediated the initiation of cell apoptosis [37]. Furthermore, the critical molecule of ER stress, GRP78, as the central area of protein folding in ER lumen, expression is upregulated to attenuate the ER stress through binding misfolded protein [38]. Therefore, the major molecules GRP78 and $\mathrm{CHOP}$ of the ER stress pathway, as well as apoptosis-related Bcl2/Bax were selected to elaborate the mechanism of ER stress on OLE against acrolein-worsening MI in rats and the antagonism of HT against acrolein in cardiomyocytes $\mathrm{H} 9 \mathrm{c} 2$ cells. The results from this study showed that the expression of GRP78, CHOP and Bax were upregulated with downregulation of Bcl2 in MI rats induced by ISO, in addition, the combination of acrolein and ISO contributed to the much higher expression of GRP78, $\mathrm{CHOP}$ and Bax, as well as much lower Bcl2 in rats.

Apart from inefficient combustion of fossil fuels, acrolein was also discovered in endogenous lipid peroxidation $[10,15]$. The World Health Organization (WHO) working group estimated that the tolerable daily intake (TDI) of acrolein is $7.5 \mu \mathrm{g} / \mathrm{kg}$ body weight [10]. Also, the recommended maximum dose of acrolein is $65 \mu \mathrm{g} / \mathrm{L}$, but this limit is usually exceeded $[39,40]$. The daily consumption of acrolein and related unsaturated aldehydes are estimated to be $5 \mathrm{mg} / \mathrm{kg}$ [17]. Hence, we selected $5 \mathrm{mg} / \mathrm{kg}$ concentration of acrolein representing the unsaturated aldehydes exposure in this study. A previous study showed that acrolein-protein adduct formation led to contractile depression [41]. 
In our results, the level of fractional shortening acrolein-protein adducts from acrolein gavage were high, but the acrolein-protein was decreased when the rats were treated with OLE by gavage for a month. In addition, cardiac parameters, EF and FS, were lower due to acrolein gavage relative to ISO treatment, while OLE reversed the low EF and FS, also, HT attenuated the cytotoxic effect of acrolein in cardiomyocyte $\mathrm{H} 9 \mathrm{c} 2$ cells. However, various metabolic pathways are involved in the body, of which the formation of 3-hydroxypropylmercapturic acid (3-HPMA) from conjugation with glutathione (GSH) represents $60-70 \%$ of total acrolein metabolism excreted in urine [15]. A recent study demonstrated that glutathione S-transferase P (GSTP)-null mice were more sensitive to ischemia-reperfusion, which prevented the conjugation of acrolein and GSH [42]. Interestingly, OLE and the main component HT proved to have antioxidant effects [43-45]. OLE treatment has improved the hepatic GSH level in aged rats [46]. In our report, OLE treatment ameliorated acrolein-exaggerating myoardial injury may partly result from OLE restoring the level of GSH that bound acrolein, which attenuated ER stress. It is well known that OLE has high content of polyphenols including OP, HT and other flavonoids [47]. Many studies have reported that OLE and the polyphenol components OP and HT could exert cardioprotective effects, anticancer capacity and antidiabetic potential [48-50]. Our results support the cardioprotective effects of OLE and the main components (HT and OP) in vivo and in vitro. However, there was no effect of OP on the mRNA expression of GRP78 and CHOP. Given that, the role of OP may need further exploration. Besides, the difference in molecular structure between OP and HT may be the other reason to explain it [51]. Furthermore, this study would be improved and more convincing if clinical and epidemiological studies were added.

In summary, our data demonstrated that OLE ameliorated the acrolein-exaggerated myoardial injury and the main components (HT and OP) attenuated the cytotoxicity of acrolein in cardiomyocyte $\mathrm{H} 9 \mathrm{c} 2$ cells through ER stress and $\mathrm{Bcl} 2$ /Bax pathways. With the deteriorating air quality and the increase of PM 2.5 values, many people are inevitably exposed to acrolein and related unsaturated aldehydes, which have negative effect on human health. Therefore, it will be helpful to prevent and treat MI if OLE and the main components are supplemented reasonably.

\section{Methods and Materials}

\subsection{Cell Culture and Reagents}

H9c2 cells were purchased from the Cell Bank of Shanghai Institute of Biochemistry and Cell Biology (Shanghai, China). H9c2 cells were cultured in Dulbecco's Modified Eagle Medium (DMEM, Gibco, Grand Island, NY, USA) supplemented with 10\% fetal bovine serum (Gibco, Grand Island, NY, USA) and 1\% penicillin-streptomycin mixed solution (Beyotime, Shanghai, China). The cells were maintained at $37{ }^{\circ} \mathrm{C}$ in a humidified $5 \% \mathrm{CO}_{2}$ atmosphere. Acrolein (95\%) was obtained from Sinopharm Chemical Reagent Company (Nanjing, China). Hydroxytyrosol (98\%) was purchased from Aladdin Biological Reagent Company (Shanghai, China). Oleuropein (95\%) was purchased from Solarbio Science and Technology Company (Beijing, China). Olive leaf extract (25\%) was provided from Sinolife United Biotech Company (Nanjing, China). ISO was purchased from Yi Feixue Bio (Nanjing, China) for inducing MI in rat.

\subsection{MTT Assay}

H9c2 cells were seeded into 96-well plates at a density of 4000 per well with $200 \mu \mathrm{L}$ medium under an environment of $37^{\circ} \mathrm{C}, 5 \% \mathrm{CO}_{2}$ and incubated overnight. After indicated treatments, methyl thiazol tetrazolium bromide (MTT, Amresco, OH, USA) solution $(20 \mu \mathrm{L}, 5 \mathrm{mg} / \mathrm{mL}$, dissolved with PBS) was added to each well and the cells were incubated at $37^{\circ} \mathrm{C}, 5 \% \mathrm{CO}_{2}$ for $4 \mathrm{~h}$. Then, dimethyl sulfoxide (DMSO, $150 \mu \mathrm{L}$ ) was added to each well to dissolve the formed formazan crystals at room temperature for $15 \mathrm{~min}$ after removing the medium. The solution was read at the absorbance of $490 \mathrm{~nm}$ with a microplate reader (Tecan/Infinite M200, Mannedorf, Switzerland). 


\subsection{Western Blot Analysis}

H9c2 cells and cardiac tissue were lysed with RIPA including PMSF (Phenylmethanesulfonyl fluoride, Beyotime, Shanghai, China). The concentration of protein was checked by BCA Protein Assay Kit (Beyotime, Shanghai, China). Subsequently, the protein was separated with sodium dodecyl sulfate-polyacrylamide gel electrophoresis (SDS-PAGE) and transferred to polyvinylidene difluoride (PVDF) membranes (Millipore, Billerica, MA, USA). The primary antibodies included: anti-GRP78 (1:1000, proteintech, Wuhan, China), anti-CHOP and anti-F4/80 (1:1000, Cell Signaling Technology, Danvers, MA, USA), anti-Bcl2 and anti-Bax (1:500, Santa Cruz Biotechnology, Dallas, TX, USA), anti- $\beta$ actin (1:1000, BOSTER, Wuhan, China), anti-GAPDH (1:1000, Beyotime, Shanghai, China). Secondary antibodies were: HRP-Conjugated AffiniPure Goat Anti-Rabbit IgG and HRP-Conjugated AffiniPure Goat Anti-Mouse IgG (1:2000, ZSGB-BIO, Beijing, China). Immunoreactive proteins were visualized using ECL Western blot detection reagents (Cell Signaling Technology, USA).

\subsection{Real-Time Polymerase Chain Reaction ( $q R T-P C R$ )}

Total RNA from cells and cardiac tissue was collected with RNAiso Plus (TaKaRaBio Technology, Dalian, China), following the manufacturer's protocol. Reverse transcription was performed using the PrimeScriptTM RT Master Mix (TakaRaBio Technology, Dalian, China) and the qRT-PCR was performed using SYBR ${ }^{\circledR}$ Premix EX TaqTM II (TakaRaBio Technology, Dalian, China) with the Applied Biosystems, 7900 Real Time PCR System (Applied Biosystems, Foster City, CA, USA). The primers were as follows: GRP78: (Forward-5'-TCAGCCCACCGTAACAATCAAGG-3', Reverse-5'-CTTCCTCAGCAAACTTCTCGGCG-3'); chop: (Forward-5'-GCACCTCCCAAAGC CCTCGC-3' ${ }^{\prime}$, Reverse- $5^{\prime}$-CCGTTTCCTAGTTCTTCCTT-3'); GAPDH: (Forward-5'-CAAGGTCATC CATGACAACTTTG-3', Reverse-5'-GTCCACCACCCTGTTGCTGTAG-3'); Bcl2: (Forward-5'-AG CCTGAGAGCAACCGAAC-3' ${ }^{\prime}$, Reverse-5'-AGCGACGAGAGAAGTCATCC-3'); Bax: (Forward5'-TTGCTACAGGGTTTCATCCAG-3', Reverse- $5^{\prime}$-TGTTGTTGTCCAGTTCATCG-3'). Expression of mRNA was calculated using the $2^{-\Delta \Delta C t}$ method and normalization with GAPDH in cells, and the level of mRNA was calculated with $2^{-\Delta \mathrm{Ct}}$ method in cardiac tissue.

\subsection{Animals and Experimental Protocol}

This animal experiment was performed in line with the recommendations in the Guide for the Care and Use of Laboratory Animals of the National Institutes of Health of China. The protocol was approved by the Institutional Animal Care and Use Committee of the Jiangsu Province Institute of Traditional Chinese Medicine. All male Sprague-Dawley rats weighing $200 \pm 20 \mathrm{~g}$ were purchased from Shanghai Silaike Laboratory Animal Ltd. (Shanghai, China) and housed in the Animal Center of Jiangsu Province Institute of Traditional Chinese Medicine under the controlled conditions (temperature of $22 \pm 1{ }^{\circ} \mathrm{C}$, a 12-h light/12-h dark cycle and humidity of $55 \pm 5 \%$ ) acclimatized to the laboratory conditions for a week before starting experiment. Rats were randomized into five groups $(n=6)$ : group (1), normal control rats received $d d \mathrm{H}_{2} \mathrm{O}$ by gavage for a month before subcutaneous injection of physiological saline for two successive days; group (2), ISO control rats received $d d \mathrm{H}_{2} \mathrm{O}$ by oral gavage for a month before subcutaneous injection of ISO $(85 \mathrm{mg} / \mathrm{kg} /$ day) for two successive days; group (3): acrolein + ISO rats received $d d \mathrm{H}_{2} \mathrm{O}$ by gavage for 28 days, then the rats received acrolein $(5 \mathrm{mg} / \mathrm{kg} /$ day) by gavage for two days before subcutaneous injection of ISO ( $85 \mathrm{mg} / \mathrm{kg} /$ day) for two successive days; group (4) and (5), rats received OLE at $200 \mathrm{mg} / \mathrm{kg} /$ day and $400 \mathrm{mg} / \mathrm{kg} /$ day for 28 days, then the rats received acrolein $(5 \mathrm{mg} / \mathrm{kg} /$ day) by gavage for two days before subcutaneous injection of ISO ( $85 \mathrm{mg} / \mathrm{kg} /$ day) for two successive days. The animals were killed, and the blood and tissue samples were taken after injection of ISO for $48 \mathrm{~h}$. Many studies reported that ISO ( $85 \mathrm{mg} / \mathrm{kg} /$ day) was used to induce MI [52-54]. Besides, ISO was detected at the different concentrations ( $5 \mathrm{mg} / \mathrm{kg} /$ day, $40 \mathrm{mg} / \mathrm{kg} /$ day, $85 \mathrm{mg} / \mathrm{kg} /$ day) to induce MI in our pilot experiment and the results indicated that ISO at $85 \mathrm{mg} / \mathrm{kg} /$ day presented the clearest effects 
on inducing MI. Wang et al. reported that consumption of unsaturated aldehydes can reach about $5 \mathrm{mg} / \mathrm{kg} /$ day, of which acrolein was selected to investigate the effect on MI [17]. The concentration of OLE referred to recent studies $[55,56]$.

\subsection{Histology}

At the end of experimental period, all animals were killed and the hearts were harvested and fixed in $10 \%$ formalin solution for $24-48 \mathrm{~h}$. After dehydration, tissues were embedded in paraffin. Sections were of the thickness of $5 \mu \mathrm{M}$ that were stained with hematoxylin-eosin and antibody Bax and F4/80. The images were analyzed by Pannoramic Viewer after scanning.

\subsection{Echocardiography}

After anesthetizing with $10 \%$ chloral hydrate, the rats were placed in decubitus supine position on the heat pad. The transthoracic echocardiography was carried out using GE ViVid-q ultrasound systems with 3-MHz linear transducer and 2-cm depth two-dimensional imaging (GE Systems, Hayozma, Tirat Carmel, Israel) when pre warmed echo transmission gel was applied to the hairless chest after injection of ISO for $48 \mathrm{~h}$.

\subsection{Enzyme-Linked Immunosorbent Assay (ELISA)}

The whole blood of the rats was collected with coagulation tube. To obtain the serum, the samples were centrifuged at speed of $2000 \mathrm{rpm}$ for $10 \mathrm{~min}$. The concentration of acrolein-protein adduct, CK-MB and LDH was measured by ELISA (Yi Feixue, Nanjing, China) according to the protocol.

\subsection{Hochest 33258 to Detect Apoptosis}

After the H9c2 cells were seeded in a 6-well plate for $24 \mathrm{~h}, \mathrm{HT}$ was added at the indicated concentration and incubated for $24 \mathrm{~h}$. Then acrolein was added at the indicated concentration for $12 \mathrm{~h}$. The cells were fixed in 4\% paraformaldehyde for $15 \mathrm{~min}$, and washed twice with PBS for $5 \mathrm{~min}$. The cells were washed twice with PBS again after being stained with $500 \mu \mathrm{L}$ Hoechst 33258 (Beyotime, Shanghai, China) for $5 \mathrm{~min}$. The stained nuclei were observed under an inverted fluorescence microscope (Olympus, Tokyo, Japan).

\subsection{Flow Cytometry}

The apoptosis of H9c2 cells was tested by Annexin-V FITC/PI kit (KeyGEN, Nanjing, China) according to the instructions. $\mathrm{H} 9 \mathrm{c} 2$ cells were harvested after the indicated treatment, and then the cells were stained with Annexin-V FITC and PI, which were analyzed by flow cytometry.

\subsection{Statistical Analyses}

Data were presented as the mean \pm standard deviation (SD) of at least three independent experiments. Statistical significance of differences between two or more groups was analyzed by student's two-tailed $t$-test or one-way analysis of variance (ANOVA). GraphPad Prism v5.0 (Graphpad Software, Inc. La Jolla, CA, USA) software was used for statistical analysis. Statistical significance was set at ${ }^{*} p<0.05,{ }^{* *} p<0.01$ and ${ }^{* * *} p<0.001$.

Acknowledgments: This work was supported by the National Natural Science Foundation of China (81472977), foundation from the Priority Academic Program Development of Jiangsu Higher Education Institutions, and Graduate Student Practice and Innovation Project of Jiangsu Province Ordinary University (SJZZ15_0117).

Author Contributions: Qing Feng and Yuyu Xu conceived and designed the experiments; Yuyu Xu performed the experiments; Yuyu Xu and Lixing Wu analyzed the data; Chaoqi $\mathrm{Xu}$ and Aochang Chen contributed reagents/materials/analysis tools; Yuyu Xu wrote the paper.

Conflicts of Interest: The authors declare no conflict of interest. 


\section{References}

1. Lozano, R.; Naghavi, M.; Foreman, K.; Lim, S.; Shibuya, K.; Aboyans, V.; Abraham, J.; Adair, T.; Aggarwal, R.; Ahn, S.Y.; et al. Global and regional mortality from 235 causes of death for 20 age groups in 1990 and 2010: A systematic analysis for the Global Burden of Disease Study 2010. Lancet 2012, 380, 2095-2128. [CrossRef]

2. Mozaffarian, D.; Benjamin, E.J.; Go, A.S.; Arnett, D.K.; Blaha, M.J.; Cushman, M.; de Ferranti, S.; Despres, J.P.; Fullerton, H.J.; Howard, V.J.; et al. Heart disease and stroke statistics-2015 update: A report from the American Heart Association. Circulation 2015, 131, e29-e322. [CrossRef] [PubMed]

3. Peters, A.; Dockery, D.W.; Muller, J.E.; Mittleman, M.A. Increased particulate air pollution and the triggering of myocardial infarction. Circulation 2001, 103, 2810-2815. [CrossRef] [PubMed]

4. Nuvolone, D.; Balzi, D.; Chini, M.; Scala, D.; Giovannini, F.; Barchielli, A. Short-term association between ambient air pollution and risk of hospitalization for acute myocardial infarction: Results of the cardiovascular risk and air pollution in Tuscany (RISCAT) study. Am. J. Epidemiol. 2011, 174, 63-71. [CrossRef] [PubMed]

5. Hampel, R.; Schneider, A.; Bruske, I.; Zareba, W.; Cyrys, J.; Ruckerl, R.; Breitner, S.; Korb, H.; Sunyer, J.; Wichmann, H.E.; et al. Altered cardiac repolarization in association with air pollution and air temperature among myocardial infarction survivors. Environ. Health Perspect. 2010, 118, 1755-1761. [CrossRef] [PubMed]

6. Brook, R.D.; Rajagopalan, S.; Pope, C.A., 3rd; Brook, J.R.; Bhatnagar, A.; Diez-Roux, A.V.; Holguin, F.; Hong, Y.; Luepker, R.V.; Mittleman, M.A.; et al. Metabolism, Particulate matter air pollution and cardiovascular disease: An update to the scientific statement from the American Heart Association. Circulation 2010, 121, 2331-2378. [PubMed]

7. Pope, C.A., 3rd; Muhlestein, J.B.; May, H.T.; Renlund, D.G.; Anderson, J.L.; Horne, B.D. Ischemic heart disease events triggered by short-term exposure to fine particulate air pollution. Circulation 2006, 114, 2443-2448. [CrossRef] [PubMed]

8. Prieto-Blanco, M.C.; Moliner-Martinez, Y.; Lopez-Mahia, P.; Campins-Falco, P. Determination of carbonyl compounds in particulate matter PM2.5 by in-tube solid-phase microextraction coupled to capillary liquid chromatography/mass spectrometry. Talanta 2013, 115, 876-880. [CrossRef] [PubMed]

9. Stevens, J.F.; Maier, C.S. Acrolein: Sources, metabolism, and biomolecular interactions relevant to human health and disease. Mol. Nutr. Food Res. 2008, 52, 7-25. [CrossRef] [PubMed]

10. Abraham, K.; Andres, S.; Palavinskas, R.; Berg, K.; Appel, K.E.; Lampen, A. Toxicology and risk assessment of acrolein in food. Mol. Nutr. Food Res. 2011, 55, 1277-1290. [CrossRef] [PubMed]

11. Altemose, B.; Gong, J.; Zhu, T.; Hu, M.; Zhang, L.; Cheng, H.; Zhang, L.; Tong, J.; Kipen, H.M.; Strickland, P.O.; et al. Aldehydes in Relation to Air Pollution Sources: A Case Study around the Beijing Olympics. Atmos. Environ. 2015, 109, 61-69. [CrossRef] [PubMed]

12. Fujioka, K.; Shibamoto, T. Determination of toxic carbonyl compounds in cigarette smoke. Environ. Toxicol. 2006, 21, 47-54. [CrossRef] [PubMed]

13. Feng, Z.; Hu, W.; Hu, Y.; Tang, M.S. Acrolein is a major cigarette-related lung cancer agent: Preferential binding at p53 mutational hotspots and inhibition of DNA repair. Proc. Natl. Acad. Sci. USA 2006, 103, 15404-15409. [CrossRef] [PubMed]

14. Moghe, A.; Ghare, S.; Lamoreau, B.; Mohammad, M.; Barve, S.; Mcclain, C.; Joshibarve, S. Molecular Mechanisms of Acrolein Toxicity: Relevance to Human Disease. Toxicol. Sci. 2015, 143, 242-255. [CrossRef] [PubMed]

15. DeJarnett, N.; Conklin, D.J.; Riggs, D.W.; Myers, J.A.; O’Toole, T.E.; Hamzeh, I.; Wagner, S.; Chugh, A.; Ramos, K.S.; Srivastava, S.; et al. Acrolein exposure is associated with increased cardiovascular disease risk. J. Am. Heart Assoc. 2014, 3, e000934. [CrossRef] [PubMed]

16. Pozsgai, G.; Bodkin, J.V.; Graepel, R.; Bevan, S.; Andersson, D.A.; Brain, S.D. Evidence for the pathophysiological relevance of TRPA1 receptors in the cardiovascular system in vivo. Cardiovasc. Res. 2010, 87, 760-768. [CrossRef] [PubMed]

17. Wang, G.W.; Guo, Y.; Vondriska, T.M.; Zhang, J.; Zhang, S.; Tsai, L.L.; Zong, N.C.; Bolli, R.; Bhatnagar, A.; Prabhu, S.D. Acrolein consumption exacerbates myocardial ischemic injury and blocks nitric oxide-induced PKCepsilon signaling and cardioprotection. J. Mol. Cell. Cardiol. 2008, 44, 1016-1022. [CrossRef] [PubMed]

18. El, S.N.; Karakaya, S. Olive tree (Olea europaea) leaves: Potential beneficial effects on human health. Nutr. Rev. 2009, 67, 632-638. [CrossRef] [PubMed] 
19. Walker, C.; Reamy, B.V. Diets for cardiovascular disease prevention: What is the evidence? Am. Fam. Physician 2009, 79, 571-578. [PubMed]

20. Tejada, S.; Pinya, S.; Del Mar Bibiloni, M.; Tur, J.A.; Pons, A.; Sureda, A. Cardioprotective effects of the polyphenol hydroxytyrosol from olive oil. Curr. Drug Targets 2017, 18, 1477-1486. [CrossRef] [PubMed]

21. Poudyal, H.; Campbell, F.; Brown, L. Olive leaf extract attenuates cardiac, hepatic, and metabolic changes in high carbohydrate-, high fat-fed rats. J. Nutr. 2010, 140, 946-953. [CrossRef] [PubMed]

22. Janahmadi, Z.; Nekooeian, A.A.; Moaref, A.R.; Emamghoreishi, M. Oleuropein offers cardioprotection in rats with acute myocardial infarction. Cardiovasc. Toxicol. 2015, 15, 61-68. [CrossRef] [PubMed]

23. Mnafgui, K.; Khlif, I.; Hajji, R.; Derbali, F.; Kraiem, F.; Ellefi, H.; Michel, T.; Halabalaki, M.; Skaltsounis, A.L.; Elfeki, A.; et al. Preventive effects of oleuropein against cardiac remodeling after myocardial infarction in Wistar rat through inhibiting angiotensin-converting enzyme activity. Toxicol. Mech. Methods 2015, 25, 538-546. [CrossRef] [PubMed]

24. Mnafgui, K.; Hajji, R.; Derbali, F.; Khlif, I.; Kraiem, F.; Ellefi, H.; Elfeki, A.; Allouche, N.; Gharsallah, N. Protective Effect of Hydroxytyrosol Against Cardiac Remodeling After Isoproterenol-Induced Myocardial Infarction in Rat. Cardiovasc. Toxicol. 2016, 16, 147-155. [CrossRef] [PubMed]

25. Wang, M.; Kaufman, R.J. Protein misfolding in the endoplasmic reticulum as a conduit to human disease. Nature 2016, 529, 326-335. [CrossRef] [PubMed]

26. Oakes, S.A.; Papa, F.R. The role of endoplasmic reticulum stress in human pathology. Ann. Rev. Pathol. 2015, 10, 173-194. [CrossRef] [PubMed]

27. Fernandez, A.; Ordonez, R.; Reiter, R.J.; Gonzalez-Gallego, J.; Mauriz, J.L. Melatonin and endoplasmic reticulum stress: Relation to autophagy and apoptosis. J. Pineal Res. 2015, 59, 292-307. [CrossRef] [PubMed]

28. Barnett, A.G.; Williams, G.M.; Schwartz, J.; Best, T.L.; Neller, A.H.; Petroeschevsky, A.L.; Simpson, R.W. The Effects of Air Pollution on Hospitalizations for Cardiovascular Disease in Elderly People in Australian and New Zealand Cities. Environ. Health Perspect. 2006, 114, 1018-1023. [CrossRef] [PubMed]

29. Zhang, K.; Kaufman, R.J. From endoplasmic-reticulum stress to the inflammatory response. Nature 2008, 454, 455-462. [CrossRef] [PubMed]

30. Ron, D.; Walter, P. Signal integration in the endoplasmic reticulum unfolded protein response. Nat. Rev. Mol. Cell Biol. 2007, 8, 519-529. [CrossRef] [PubMed]

31. Walter, P.; Ron, D. The unfolded protein response: From stress pathway to homeostatic regulation. Science 2011, 334, 1081-1086. [CrossRef] [PubMed]

32. Tabas, I.; Ron, D. Integrating the mechanisms of apoptosis induced by endoplasmic reticulum stress. Nat. Cell Biol. 2011, 13, 184-190. [CrossRef] [PubMed]

33. Prola, A.; Silva, J.P.; Guilbert, A.; Lecru, L.; Piquereau, J.; Ribeiro, M.; Mateo, P.; Gressette, M.; Fortin, D.; Boursier, C.; et al. SIRT1 protects the heart from ER stress-induced cell death through eIF2alpha deacetylation. Cell Death Differ. 2017, 24, 343-356. [CrossRef] [PubMed]

34. Shimizu, Y.; Hendershot, L.M. Oxidative folding: Cellular strategies for dealing with the resultant equimolar production of reactive oxygen species. Antioxid. Redox Signal. 2009, 11, 2317-2331. [CrossRef] [PubMed]

35. Groenendyk, J.; Agellon, L.B.; Michalak, M. Coping with endoplasmic reticulum stress in the cardiovascular system. Ann. Rev. Physiol. 2013, 75, 49-67. [CrossRef] [PubMed]

36. Thuerauf, D.J.; Marcinko, M.; Gude, N.; Rubio, M.; Sussman, M.A.; Glembotski, C.C. Activation of the unfolded protein response in infarcted mouse heart and hypoxic cultured cardiac myocytes. Circ. Res. 2006, 99, 275-282. [CrossRef] [PubMed]

37. Fu, H.Y.; Okada, K.; Liao, Y.; Tsukamoto, O.; Isomura, T.; Asai, M.; Sawada, T.; Okuda, K.; Asano, Y.; Sanada, S.; et al. Ablation of C/EBP homologous protein attenuates endoplasmic reticulum-mediated apoptosis and cardiac dysfunction induced by pressure overload. Circulation 2010, 122, 361-369. [CrossRef] [PubMed]

38. Paton, A.W.; Beddoe, T.; Thorpe, C.M.; Whisstock, J.C.; Wilce, M.C.; Rossjohn, J.; Talbot, U.M.; Paton, J.C. AB5 subtilase cytotoxin inactivates the endoplasmic reticulum chaperone BiP. Nature 2006, 443, 548-552. [CrossRef] [PubMed]

39. Beauchamp, R.O., Jr.; Andjelkovich, D.A.; Kligerman, A.D.; Morgan, K.T.; Heck, H.D. A critical review of the literature on acrolein toxicity. Crit. Rev. Toxicol. 1985, 14, 309-380. [CrossRef] [PubMed]

40. Henning, R.J.; Johnson, G.T.; Coyle, J.P.; Harbison, R.D. Acrolein Can Cause Cardiovascular Disease: A Review. Cardiovasc. Toxicol. 2017, 17, 227-236. [CrossRef] [PubMed] 
41. Luo, J.; Hill, B.G.; Gu, Y.; Cai, J.; Srivastava, S.; Bhatnagar, A.; Prabhu, S.D. Mechanisms of acrolein-induced myocardial dysfunction: Implications for environmental and endogenous aldehyde exposure. Am. J. Physiol. Heart Circ. Physiol. 2007, 293, H3673-H3684. [CrossRef] [PubMed]

42. Conklin, D.J.; Guo, Y.; Jagatheesan, G.; Kilfoil, P.J.; Haberzettl, P.; Hill, B.G.; Baba, S.P.; Guo, L.; Wetzelberger, K.; Obal, D.; et al. Genetic Deficiency of Glutathione S-Transferase P Increases Myocardial Sensitivity to Ischemia-Reperfusion Injury. Circ. Res. 2015, 117, 437-449. [CrossRef] [PubMed]

43. Rigane, G.; Bouaziz, M.; Sayadi, S.; Salem, R.B. Effect of storage on refined olive oil composition: Stabilization by addition of chlorophyll pigments and squalene. J. Oleo Sci. 2013, 62, 981-987. [CrossRef] [PubMed]

44. Bali, E.B.; Ergin, V.; Rackova, L.; Bayraktar, O.; Kucukboyaci, N.; Karasu, C. Olive leaf extracts protect cardiomyocytes against 4-hydroxynonenal-induced toxicity in vitro: Comparison with oleuropein, hydroxytyrosol, and quercetin. Planta Med. 2014, 80, 984-992. [CrossRef] [PubMed]

45. Moudache, M.; Colon, M.; Nerin, C.; Zaidi, F. Phenolic content and antioxidant activity of olive by-products and antioxidant film containing olive leaf extract. Food Chem. 2016, 212, 521-527. [CrossRef] [PubMed]

46. Coban, J.; Oztezcan, S.; Dogru-Abbasoglu, S.; Bingul, I.; Yesil-Mizrak, K.; Uysal, M. Olive leaf extract decreases age-induced oxidative stress in major organs of aged rats. Geriatr. Gerontol. Int. 2014, 14, 996-1002. [CrossRef] [PubMed]

47. Zoric, N.; Kopjar, N.; Kraljic, K.; Orsolic, N.; Tomic, S.; Kosalec, I. Olive leaf extract activity against Candida albicans and C. dubliniensis-The in vitro viability study. Acta Pharm. 2016, 66, 411-421. [CrossRef] [PubMed]

48. Navarro, M.; Morales, F.J. Evaluation of an olive leaf extract as a natural source of antiglycative compounds. Food Res. Int. 2017, 92, 56-63. [CrossRef] [PubMed]

49. Boss, A.; Bishop, K.S.; Marlow, G.; Barnett, M.P.; Ferguson, L.R. Evidence to Support the Anti-Cancer Effect of Olive Leaf Extract and Future Directions. Nutrients 2016, 8, 513. [CrossRef] [PubMed]

50. Dekanski, D.; Selakovic, V.; Piperski, V.; Radulovic, Z.; Korenic, A.; Radenovic, L. Protective effect of olive leaf extract on hippocampal injury induced by transient global cerebral ischemia and reperfusion in Mongolian gerbils. Phytomed. Int. J. Phytother. Phytopharm. 2011, 18, 1137-1143. [CrossRef] [PubMed]

51. Gentile, L.; Uccella, N.; Sivakumar, G. Soft-MS and Computational Mapping of Oleuropein. Int. J. Mol. Sci. 2017, 18, 992. [CrossRef] [PubMed]

52. Wei, B.; You, M.G.; Ling, J.J.; Wei, L.L.; Wang, K.; Li, W.W.; Chen, T.; Du, Q.M.; Ji, H. Regulation of antioxidant system, lipids and fatty acid beta-oxidation contributes to the cardioprotective effect of sodium tanshinone IIA sulphonate in isoproterenol-induced myocardial infarction in rats. Atherosclerosis 2013, 230, 148-156. [CrossRef] [PubMed]

53. Tiwari, R.; Mohan, M.; Kasture, S.; Maxia, A.; Ballero, M. Cardioprotective potential of myricetin in isoproterenol-induced myocardial infarction in Wistar rats. Phytother. Res. 2009, 23, 1361-1366. [CrossRef] [PubMed]

54. Sahu, B.D.; Anubolu, H.; Koneru, M.; Kumar, J.M.; Kuncha, M.; Rachamalla, S.S.; Sistla, R. Cardioprotective effect of embelin on isoproterenol-induced myocardial injury in rats: Possible involvement of mitochondrial dysfunction and apoptosis. Life Sci. 2014, 107, 59-67. [CrossRef] [PubMed]

55. Zare, L.; Esmaeili-Mahani, S.; Abbasnejad, M.; Rasoulian, B.; Sheibani, V.; Sahraei, H.; Kaeidi, A. Oleuropein, chief constituent of olive leaf extract, prevents the development of morphine antinociceptive tolerance through inhibition of morphine-induced L-type calcium channel overexpression. Phytother. Res. 2012, 26, 1731-1737. [CrossRef] [PubMed]

56. Kaeidi, A.; Esmaeili-Mahani, S.; Sheibani, V.; Abbasnejad, M.; Rasoulian, B.; Hajializadeh, Z.; Afrazi, S. Olive (Olea europaea L.) leaf extract attenuates early diabetic neuropathic pain through prevention of high glucose-induced apoptosis: In vitro and in vivo studies. J. Ethnopharmacol. 2011, 136, 188-196. [CrossRef] [PubMed]

(C) 2018 by the authors. Licensee MDPI, Basel, Switzerland. This article is an open access article distributed under the terms and conditions of the Creative Commons Attribution (CC BY) license (http:/ / creativecommons.org/licenses/by/4.0/). 